\title{
2.5 \\ MÅLARES NÄTVERK, RELATIONER \\ OCH SAMARBETEN. \\ MÅLERIET I LJUSDAL \\ TILL OCH MED ANDERS ERIK ÄDEL
}

Anders Assis

I detta kapitel beskrivs och diskuteras hur enskilda målares inbördes kontakter och samarbeten kan ha gjort avtryck i målarnas respektive sätt att arbeta. Hur de, som verksamma inom en och samma lokala målerikonvention, traderade, förvaltade och utvecklade en gemensam form- och motivvärld. Detta görs genom att visa måleriet i Ljusdal och dess utveckling från 1700-talets sista decennier till omkring $1850 \mathrm{och}$ hur några av dess mer produktiva företrädare verkat. Kopplingarna målarna emellan analyseras med utgångspunkt i hur motiven tillämpades, fördes vidare och varierades inom gruppen.

Tidigare forskning har lyft fram Anders Erik Ädel (1809-1888) som den främste av målarna inom den tradition som har kallats "ädelmåleri" (Andersson 2000:92). Ädels insats har på senare tid skärskådats och delvis omvärderats och tidigare målare har lyfts fram som viktiga medaktörer i skapandet av socknens säregna måleri (Cavallin 2010; Assis 2013, 2016ab, 2017). Slutsatserna bygger både på signerade verk och verk som dokumenterats genom skriftliga källor samt verk som attribuerats genom konnässörskapsanalys. Bland annat har ett omfattande bildmaterial och stora mängder föremål studerats och jämförts. Den nya bilden gör också att den folkligt förankrade termen "ädelmåleri" förefaller alltmer problematisk. Måleriet har kommit att uppkallas efter Anders Erik Ädel, men hur berättigad är benämningen egentligen?

\section{Det folkliga måleriet i förändring}

En lokal stil utvecklades i Ljusdal vid tiden omkring sekelskiftet 1800. Bara en generation tidigare hade inredningskulturen i området präglats 
av helt andra ideal. Flera bevarade väggmålerifragment ${ }^{46}$ visar att de stilpreferenser som var rådande vid mitten av 1700-talet, i allt väsentligt liknade det interiörmåleri som fanns i såväl Dellenbygden som i Voxnandalen. Denna utveckling i Ljusdal är inget unikum. Under sent 1700-tal och tidigt 1800-tal kom de stilar och motiv som tidigare varit gångbara i stora delar av landet, på många håll att successivt ersättas med mer lokalt utvecklade stilideal.

\section{Nya stilar, nya kontakter}

Bevarade spår av det sena 1700-talets inredningskultur tyder på att hantverkarna i Ljusdalsbygden hade påverkats starkt av rokoko och gustaviansk stil, och senare på 1800-talet även av empiren. Samma influenser kan anas även på andra platser, men på olika sätt och i varierande omfattning. I Ljusdal fanns under 1700-talets andra hälft en mängd lokala målare och snickare, av vilka flera redan i unga år hade skickats på lära till skråutbildade hantverkare i Hudiksvall, Söderhamn och Gävle, vilket framgår av tidiga husförhörslängder (Sinha 2001; Assis 2018, Ljusdal A Ia:1a och 1b). Detta antyder att det fanns en öppenhet och ett intresse för nyheter samt tillgång till lokala hantverkare som kunde göra något av dem. Dessa kom att fungera som spridare av kunskap och stilar, som påverkade utvecklingen av det lokala formspråket.

Det estetiska uttryckets förändring under perioden omfattade såväl snickeriet som måleriet. I flera tongivande hantverkarfamiljer utövades dessutom både måleri och snickeri (Assis 2018). Även enskilda individer som ägnade sig åt flera olika hantverk är belagda (Assis 2016). Det har visat sig att det just i övre Ljusnandalen under 1700-talet fanns flera hantverkare som kombinerade flera sysslor, såsom Olof Johansson (1718-1792), Arvid Andersson (1762-1826) och Olof Henriksson (1793-1861) (Assis 2016). Kanske ska dessa inte ses som enskilda undantag, utan snarare som en naturlig del av hälsingarnas sätt att försörja sig genom mångsyssleri. En parallell i Forsa socken visar också hur en enskild hantverkare, Jöns Månsson, fortfarande på 1800-talet kunde påverka och delvis dominera ett lokalt möbelformspråk i såväl måleri som snickeri.

Det sena 1700-talets hantverkare hade olika källor att plocka influenser från. De enskilt viktigaste influenserna till den genomgripande

46. Fragment från Per-Ers i Hamre 1735, i Norrkämsta daterat 1752 och från Simanbo 1753 (LjM, OPR). 
förändringen som sker i Ljusdal vid denna tid går troligen att tillskriva två skråutbildade mästare: Magnus Granlund (1711/1712-1779) från Härnösand och Paul Hallberg (1734-1789) från Hudiksvall (Aronsson 2014; Brännberg 2007; Rapp 1968). Under 1770-talet etablerade flera lokala hantverkare i Ljusdal personliga kontakter med dem i samband med att de förnyade socknens kyrkoinredning. De efterlämnade verken i sig kom också under lång tid framöver att bli inspirationskälla för senare arbeten (se fig. 1). Detta har påvisats tidigare (jfr Andersson 2000), men de personliga kontakterna mellan de lokala hantverkarna och dessa mästare har endast tangerats (jfr Telhammer 1995; Assis 2018).
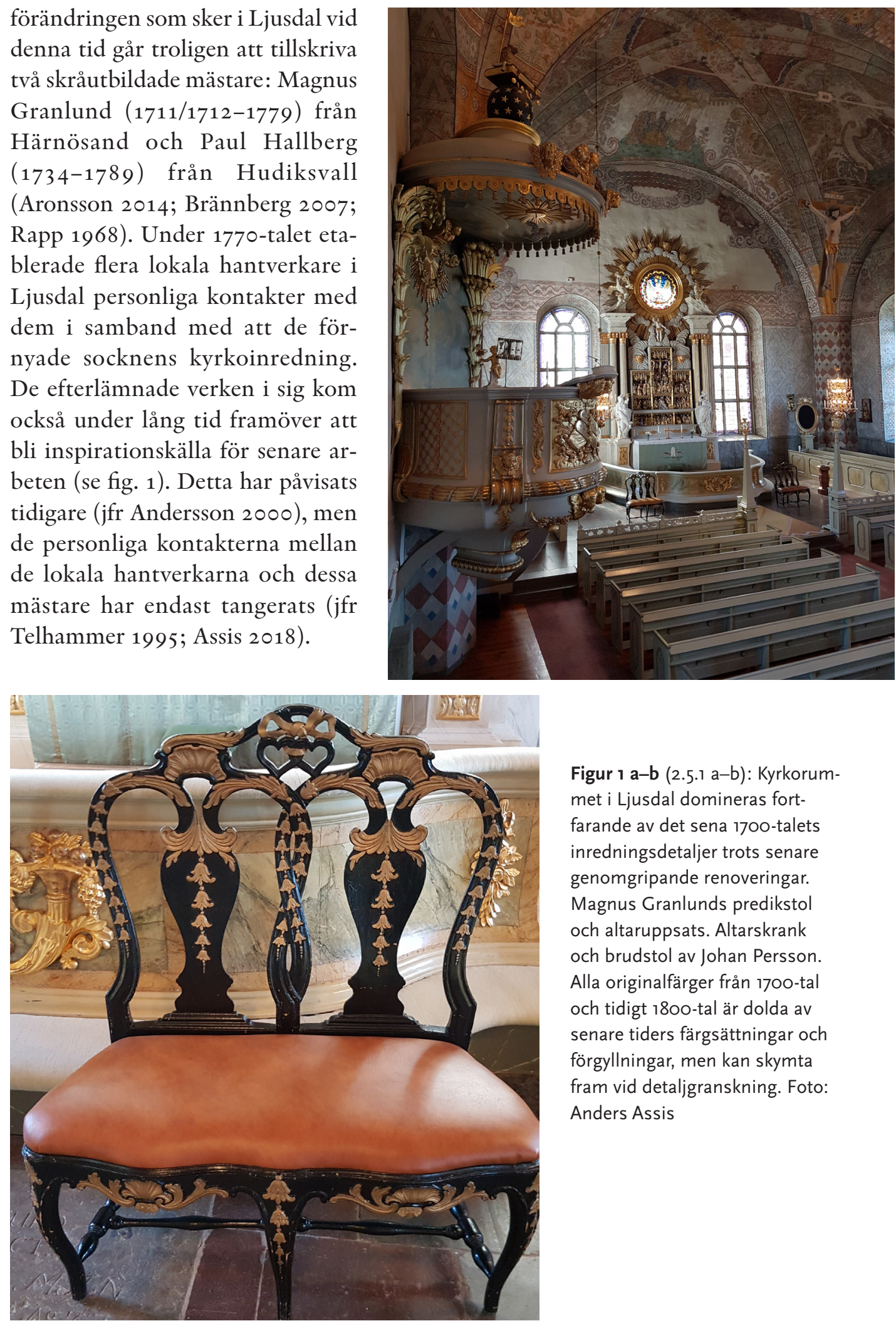

Figur 1 a-b (2.5.1 a-b): Kyrkorummet i Ljusdal domineras fortfarande av det sena 1700-talets inredningsdetaljer trots senare genomgripande renoveringar. Magnus Granlunds predikstol och altaruppsats. Altarskrank och brudstol av Johan Persson. Alla originalfärger från 1700-tal och tidigt 1800-tal är dolda av senare tiders färgsättningar och förgyllningar, men kan skymta fram vid detaljgranskning. Foto: Anders Assis 


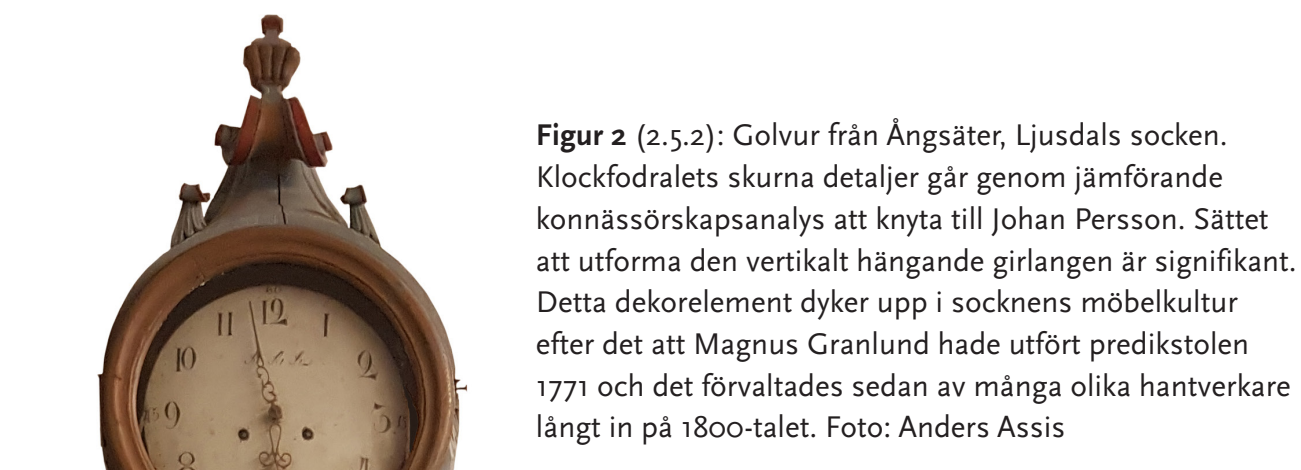

Ett exempel på en hantverkare som kom att lära känna de två mästarna var den lokale snickaren och bildhuggaren Johan Persson (1746-1817). Han arbetade vid ett par tillfällen tillsammans med Magnus Granlund när denne, som vistades i Ljusdal mellan 1770 och 1774, utförde inredningar för kyrkorna i Ljusdal, Järvsö, Bjuråker och Hög. Perssons bidrag var integrerade delar i Granlunds arbeten, vilket visar att de arbetade tillsammans (Telhammer 1995; Assis 2018). Persson kom senare även att ta egna kyrkouppdrag 47 och var mästaren bakom de två brudstolar från 1785 som finns i Ljusdals kyrka (Ljusdals kyrkoräkenskaper 1785)..$^{8}$ Brudstolarnas specifikt utformade detaljer kan ligga till grund för vidare attribueringar. Persson kan därför genom konnässörskapsanalys tillskrivas ett flertal profana möbler och var således en av de lokala hantverkare som aktivt kom att tradera delar av Granlunds motivvärld och befästa den i den lokala stilpreferensen (se fig. 2).

Paul Hallberg och hans lärlingar utförde målningsarbeten i Ljusdals kyrka åren 1777-1778 (Telhammer 1980, 1995). Arbetet uppgick till 336 dagsverken (Ljusdal L Ib:4) och gällde alla nya inventarier som tillkommit liksom även en del äldre inredning. Inget av ytskikten finns idag bevarat i orört skick, ${ }^{49}$ men en äldre

47. Persson tillverkade ett altarskrank, delar till orgelverkets fasad i Ljusdal åren 1777-1778 samt en ny predikstol åt Färila kyrka 1802, vilken dock brann 1837 .

48. De två brudstolarna har i tidigare kyrkobeskrivningar felaktigt angetts vara tillverkade 1838 .

49. Möjligen är färgsättningen i predikstolens himmelsbakgrund delvis Hallbergs, om än bättrad. Den ursprungli- 


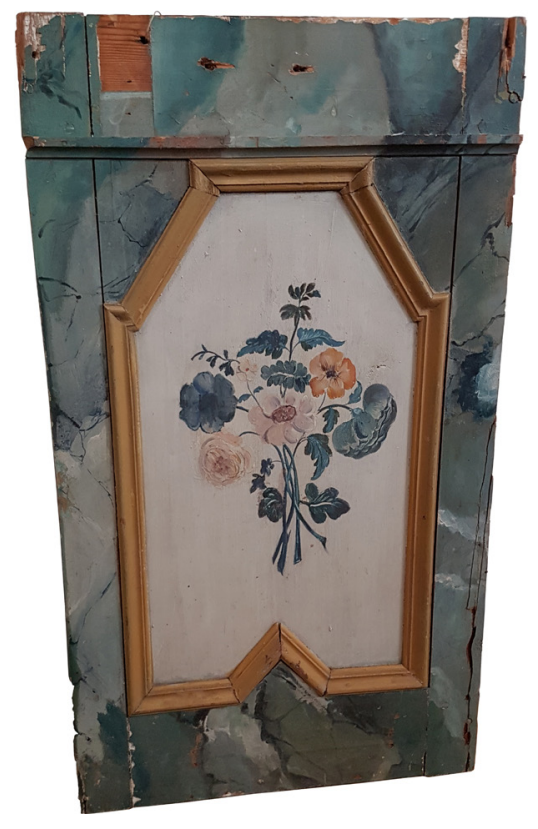

brudstol från Kårböle kapell (illustration i Tunander \& Nessle 1995) kan visa hur Hallberg och hans lärlingar dekorerade kyrkoinventarier vid tiden, och kanske så även i Ljusdal. Dess marmorering i blått kan jämföras med den på kyrkbänksdörrarna från Harmångers kyrka, utförd av Hallberg och hans gesäller 1770, som finns deponerade i Hälsinglands museum. Daterade profana möbler vittnar om att bruna färgställningar varit en sorts konvention i Ljusdal fram till och med 1760-talet, och att den blå marmorering som kom att bli ett signum för möbler från Ljusdal, introducerades omkring 1780 . Skiftet av stilideal påvisar således en tidsmässig överensstämmelse med kyrkoinredningarnas mode, och det är därför ett rimligt antagande att det var just detta som inspirerade till denna utveckling inom socknens möbelmåleri. Statusbetonade skåp från tiden kunde utöver marmoreringen i blått även förses med vita dörrspeglar vars blomstermotiv ytterligare förstärker kopplingen till Hallbergs arbeten (se fig. 3).

ga färgsättningen av predikstolen kan på vissa ställen anas genom lager av senare förgyllningar.
Figur 3 a-b (2.5.3 a-b): Kyrkbänksdörr från Harmånger, målad 1770 av Hallberg och hans lärlingar (t.v.). Skåp från Ångsäter, Ljusdal, idag i Ljusdalbygdens museums samlingar, målat av Per Jonsson (1726-1810) (t.h.). Foto: Anders Assis 
Flera lokala hantverkare bör ha gjort Hallbergs bekantskap ${ }^{50}$ och lokala målare kan även ha deltagit praktiskt i arbetet, då församlingen hade lovat att ställa upp med dagsverken för bland annat "färgors rifvande" (Ljusdal KI:2:8).

\section{Målarna från Kolsvedja}

Bland hantverkare på landsbygden var det vanligt att kunskaper traderades inom familjen och vanligen lärde yngre av de äldre. Verktyg, målarredskap, mallar och schabloner ärvdes och återanvändes (Nyström 2012). Motiv- och formspråk förvaltades över generationerna vilket stärker bilden av traditionens makt och målarnas beroende av sina sociala sammanhang. Ett sådant exempel från Ljusdal är två generationer målare i byn Kolsvedja, till vilka ett stort antal möbler har kunnat knytas (Assis 2016b) och där det tydligt går att följa traditionens utveckling genom ett generationsskifte. Den yngre målaren, Jon Persson, förvaltade fadern Per Jonssons motivvärld, men anpassade och utvecklade den också efter tidens och sina egna förutsättningar. Muntlig tradition har utpekat den äldre av dem som inredningsmålare och den yngre är i skriftliga källor belagd som målare. Familjen förefaller ha haft en stabil ekonomi och ett högt anseende i socknen, och den yngre av dem utförde även mindre måleriuppdrag åt kyrkan.

\section{Per Jonsson}

De möbler som målades av bonden Per Jonsson (1726-1810) har, i avsaknad av signerade verk, attribuerats till honom via verk som kunnat knytas till hans son (Assis 2016b). Det är inte klarlagt hur Jonsson lärde sig att måla men vissa inslag i hans manér, som till exempel sättet att marmorera, tyder på kontakt med någon skolad målare. Även den samtida Jon Jonsson (1736-1806) hade enligt uppgift lärt sig hantverket lokalt (Assis 2016b), så möjligen fanns det någon mer erfaren målare med utblickar, som tog sig an målaraspiranter i Ljusdal vid mitten av 1700-talet. Bristfälligt källmaterial försvårar dock närmare studier av deras eventuella kontakter under ungdomsåren.

Det är ett högst rimligt antagande att Per Jonsson träffade Paul Hallberg under dennes arbete i kyrkan, då Jonssons svågrar, Johan Frankenberg och Olof Frankenberg, bägge var engagerade i kyrkans utsmyck-

50. Utredning av Ljusdals kyrkoräkenskaper och hantverkare (LjM OPR). 
Figur 4 (2.5.4): Golvursfodral i rokoko, målat av Per Jonsson 1803 . I privat ägo. Observera Jonssons tolkning av Granlunds vertikala girlanger samt uttrycket i rosetten vilket känns igen från skåpet från Ångsäter i figur 3. Foto: Anders Assis

ning. ${ }^{51}$ Det tidigaste verk som i dagsläget har kunnat attribueras till Jonsson är utfört under 1780-talets första hälft, ${ }^{52}$ och dess marmorering i blått har således ett tidsmässigt sammanhang med Hallbergs arbeten i kyrkan. Jonsson var redan då förhållandevis tekniskt skicklig, vilket talar för att han bör ha målat redan tidigare. Från denna tid och framåt dekorerade Jonsson många möbler med en marmorering i blått. Hypotesen att just Hallbergs arbeten kan ha inspirerat Jonsson stärks av ett skåp som han målat med Hallbergs arbete i Ljusdals kyrka som direkt förlaga (Kämsby 1999). Kopplingen mellan Jonssons formspråk och Hallbergs styrks ytterligare av en jämförelse med kyrkbänksdörrarna från Harmånger (se fig. 3).

Jonssons äldsta daterade verk är från år $1793 .{ }^{.3} \mathrm{Un}$ der de sista åren i livet var han produktiv och hans verk håller hög klass. Bevarat material tyder på att hans blomstermåleri utvecklades under denna period och stilmässigt kan hans verk beskrivas som rokoko, vilket exemplifieras genom ett golvursfodral från 1803 (se fig. 4). Enligt den muntliga traditionen ska Jonsson även ha utfört inredningsmålerier och möjligen kan han vara upphovsmannen bakom inredningsfragment från gården Höga i Ljusdal, bevarat i privat ägo. Motivet inne-

51. Expeditionsbefallningsman Johan Frankenberg (17321805) och Olof Frankenberg (1738-1819). Olof var komminister 1773-1786 i Ljusdal och senare kyrkoherde från 1801 (Norrman 2001).

52. Odaterad möbel vars ålder har kunnat bedömas genom identifiering av ursprunglig ägare.

53. En kista målad den 10 april 1793, till Jonssons egen dotter Karin (f. 1771). Privat ägo. 
fattar en rocaille, som i utförandet uppvisar påtagliga likheter med Jonssons manér. Det är dock svårt att göra en direkt jämförelse med hans möbelmåleri, då fragmentet är utfört i mager färg på väv och innehåller förhållandevis få motiv och stildetaljer.

\section{Jon Persson}

Att Per Jonssons son Jon Persson (1760-1845) målade är belagt i Ljusdals kyrkoräkenskaper vid ett flertal tillfällen under 1800-talets två första decennier (Ljusdal LI:12). Flera verk har kunnat attribueras till honom genom en rad starka indicier (Assis 2016b). Persson övertog delar av faderns repertoar men blev aldrig riktigt lika tekniskt skicklig. Det syns exempelvis i hans målade bokstäver, vilka inte är utförda med samma elegans som faderns. Ett par marmorerade kistor, ${ }^{54}$ odaterade men som genom kännedom om respektive ursprungsägare kan antas var utförda omkring 1820, visar att han heller inte marmorerade lika skickligt som fadern. Kanske var detta, möjligen i samverkan med ett skiftande mode, orsak till att han i större utsträckning kom att ägna sig åt blomstermåleri vilka utfördes på monokrom bakgrund. Han kopierade faderns former såsom blommor och roccailler och efter faderns död utvecklade han denna repertoar vidare genom tillägg av nya ornament. Det är rimligt att anta att Persson, liksom fadern, troligen var verksam även som inredningsmålare. Ett fragmentariskt bevarat inredningsfragment från gården Hans-Ers i Ångsäter kan möjligen knytas till honom. ${ }^{55}$ Perssons hustru var född på gården och måleriet, vilket är utfört på lerklining, uppvisar stora likheter med hans handlag. Det är dock, liksom i fallet med fadern, svårt att helt säkerställa denna attribuering i brist på referensmaterial.

\section{Arve i Stavsäter, Hindriks-Olle och Anders Erik Ädel}

Det var inte enbart inom familjer som hantverkskunskaper traderades, utan även mellan familjer. Många av de aktiva målarna i Ljusdal hade påvisbara sociala band till varandra. Flera av dem var avlägset släkt och/

54. En i privat ägo, illustrerad i Assis 2016 och en i Kungliga Vitterhetsakademiens ägo.

55. Inredning i huvudbyggnadens mellankammare utförd på puts direkt på timret från omkring 1790. Dokumenterad i samband med renoveringsarbeten 2011 (LjM OPR). 
eller umgicks i samma kretsar. Detta är intressant i sig, men belägger inga mästar-lärlingsförhållanden. En viktig kedja av mästar-lärlingsförhållanden som går utanför målarnas närmaste släktkrets och som har kunnat beläggas, är den från Arvid Andersson i Stavsäter via Hindriks-Olle i Kallmyr och till Anders Erik Ädel i Måga. Dessa tre målare hade familjeband på längre håll. Deras hantverksmässiga relationer har kunnat beläggas genom arbeten de har utfört tillsammans (Cavallin 2010; Assis 2017). Trion var central för det lokala måleriets utveckling och de var alla mycket produktiva. Tillsammans står de bakom en betydande del av det bevarade inredningsmåleriet i Ljusdals socken.

\section{Arve $i$ Stavsäter}

Bonden och hantverkaren Arvid Andersson i Stavsäter (1762-1826) gick enligt uppteckningar under benämningen Arve i Stavsäter (Assis 2016b). Han målade, murade, snickrade och tecknade. Troligen lärde han sig måla i ungdomen, men det är okänt när och genom vem. Arve hade liksom sina föräldrar kontakter med flera äldre målare i Ljusdal, men i vilken grad någon av dem hade direkt betydelse för Arves utveckling är ännu okänt. I såväl huvuddrag som detaljer hade Arves måleri många beröringspunkter med det som har utförts av Per Jonsson i Kolsvedja, men inga direkta kopplingar de två familjerna emellan har varit möjliga att belägga. ${ }^{56}$

Arvid Anderssons inredningsmåleri är känt genom tre bevarade inredningar: en i Sjövästa, Ljusdal och en från Ed i Färila, bägge daterade 1807 samt en odaterad i Öje, Järvsö. ${ }^{57}$ Därtill finns ytterligare några andra delvis fotodokumenterade. Inredningen från Öje, vilken är bevarad på originalplats, är troligen den äldsta. Den är förmodligen utförd på 1790-talet och är hans enda kända signerade verk. Dess centralmotiv har ett upplägg som för tankarna till en altaruppsats i rokoko, såsom den i Kuggörarnas kapell från 1770 (Nylander et al. 2016:76ff), och motivdetaljer i flera andra av inredningens väggfält styrker hypotesen att kyrkliga inredningar kan ha varit en inspiration. Det finns ett stort antal bevarade föremål och möbler som genom konnässörskapsanalys kan

56. Kolsvedjafamiljen hade sociala kopplingar till Stavsäter vid denna tid, till exempel såsom varande dopvittnen till barn från byn, men ingen känd koppling direkt till familjen i gården Arves, Stavsäter 4.

57. Utigården i Sjövästa. Östigården i Ed, idag i gamla bakstugan på Färila hembygdsgård. Ol-Ingemars i Öje. 
förmodas vara utförda av Arve i Stavsäter. Många är odaterade, men i en del av dem, förmodat senare verk, kan även tydliga drag av gustaviansk stil skönjas. Den samlade bilden av Arves verk visar att han målade med inspiration från tapeter och kyrkoinredningar. Men materialet påvisar även att han var kreativ och gjorde egna kompositioner.

Arvid Andersson hade själv inga söner, och huruvida hans dotter Margta Arvidsdotter målade är inte känt. Flera yngre målare hade kontakter med Andersson och hans familj, och i flera fall är det rimligt att anta att han påverkade deras måleri. En av dessa var Olof Henriksson, eller Hindriks-Olle som han kallades.

\section{Hindriks-Olle i Kallmyr}

Olof Henriksson (1793-1861) var bondson, torpare och målare och gick under den folkliga benämningen Hindriks-Olle. Hans familj hade kopplingar till Arve i Stavsäter, som också var hans gudfar. Arve bör ha varit den som introducerade honom i måleriet och möjligen kan det faktum att Hindriks-Olle hörde illa ha bidragit till hans val av livsgärning (Ljusdal AI:5a:9). Han gifte sig 1818 med Brita Johansdotter (1794-1872) som även hon hade en koppling till hantverket, genom sin farfar målaren Olof Johansson i Måga (1718-1792) (Assis 2016ab).

I yngre tonåren dekorerade Hindriks-Olle, under Arves ledning, en kammare i Utigården i Sjövästa, Ljusdal (Cavallin 2010; Assis 2016ab). Inredningens måleri var utfört efter mönstret på en modern tryckt tapet. Bruket av förlagor torde Hindriks-Olle således fått med sig från tiden då han lärde hantverket av Arve. Flera senare inredningar tyder på att han fortsatte använda liknande inspiration även under tiden som självständig målare: hans kokongliknande former och snirkliga strån kan vara inspirerade av en tryckt tapet från omkring 1800 (se fig. 5)..$^{8}$ Hans målade draperier från Utigården i Sunnanås kan vara inspirerade av en motsvarighet till Torsselius tapetmålarbok (Andersson 2000:135; Assis 2014, 2016a).

Arves och Hindriks-Olles möbelmåleri har många gemensamma drag. Dels i helheter såsom upplägg och motivval, dels i detaljer och manér, inte minst vad gäller blomstermåleri och bokstavsformer. Det kan i vissa fall vara mycket svårt att skilja den enes verk från den andres. I sådana fall krävs nära studier av penselföring tillsammans med ma-

58. Tack till Ingela Broström som uppmärksammat mig på denna tapetförlaga. 

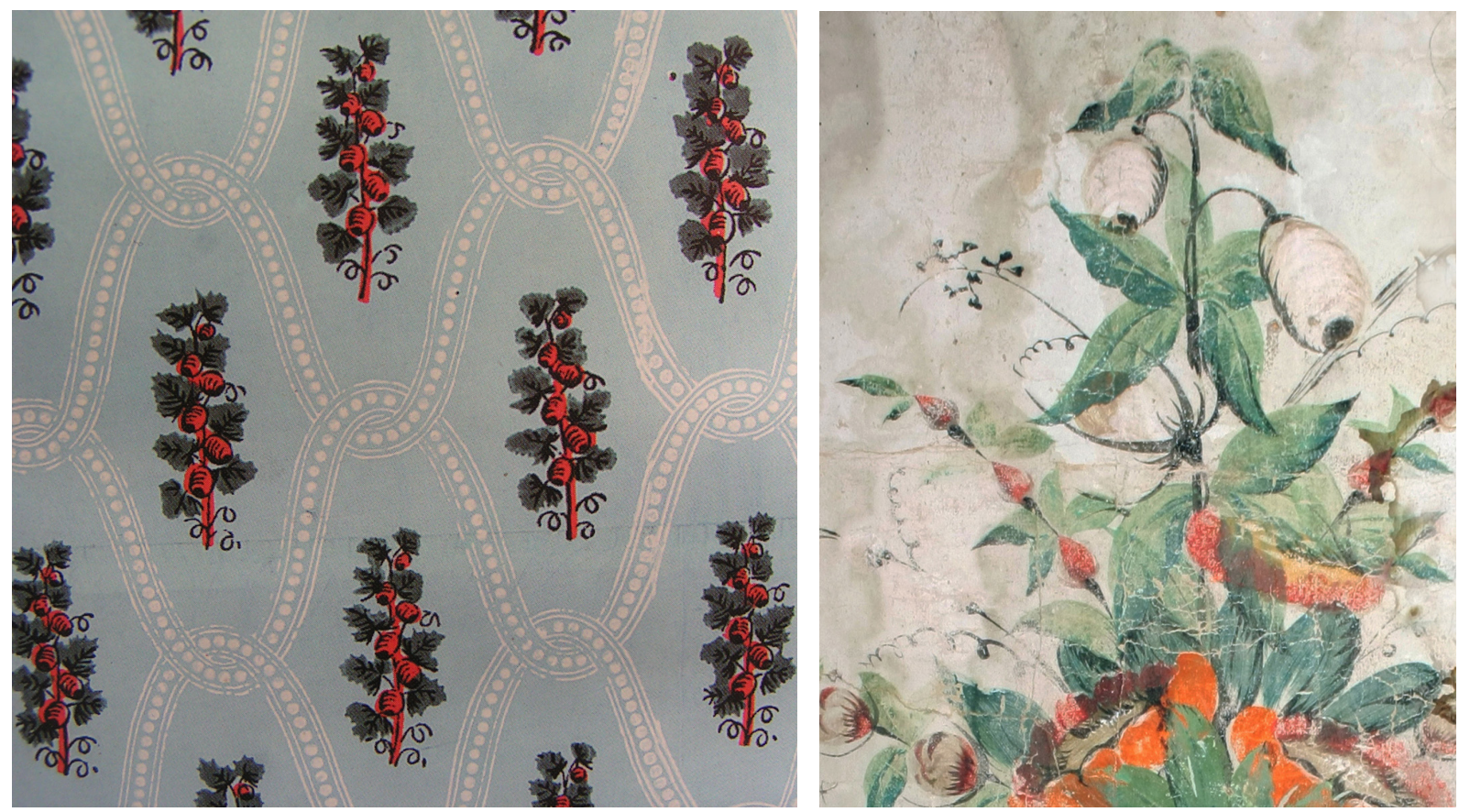

terialkaraktärisering för att kunna fälla ett avgörande. Hindriks-Olles palett har analyserats utifrån interiörmålerier från gårdarna Simmes i Välje och Jon-Pers i Nore, och där finns spår av bland annat malakit och massicot (se vidare kapitel 3.5 Konstteknologiska undersökningar av hälsingemåleri). Arves respektive Hindriks-Olles interiörmåleri är däremot lättare att skilja åt, främst på grund av deras respektive komposition och motiv. Hindriks-Olles bruk av samtida förlagor kan ha varit en orsak till att han lämnade rokokons former och kom att måla i gustaviansk stil. Många av Arves motiv levde kvar i Hindriks-Olles repertoar men till denna fogade han också många nya detaljer. När Hindriks-Olle började arbeta på egen hand är inte känt, och med ytterst få kända daterade verk är hans måleri svårt att ordna kronologiskt. ${ }^{59}$

Hindriks-Olle hade åtminstone två yngre målare som lärlingar, sonen Johan Olofsson ${ }^{60}$ och Anders Erik Ädel. Johan, som aldrig flyttade hemifrån eller gifte sig, kan mycket väl periodvis ha hjälpt fadern och möjligen är det därför svårt att särskilja hans handlag från faderns. Ädel målade med Hindriks-Olle under första delen av 1830-talet (Assis

59. Endast två daterade verk är kända: en inredning från 1830 från Simmes i Välje samt en kista från 1832, ursprungligen från Utigården i Sunnanås, Ljusdals socken. Den tidigare undersökt inom projektet, se vidare kapitel 3.5 Konstteknologiska undersökningar av hälsingemåleri. Den senare i privat ägo.

60. Johan (Johannes) Olofsson (1819-1888) (Assis 2016a:83ff). 
2017). Två interiörer efter Hindriks-Olle som tydligt bär spår av Ädels hand är de från Jon-Pers i Nore och Pell-Pers i Noresbo ${ }^{61}$ vilka båda tillkom i mitten av 1830-talet. Möjligen kan Ädel även ha varit delaktig i ytterligare ett par kända interiörer. ${ }^{62}$

\section{Anders Erik Ädel}

Ett exempel där hantverkskunskaper traderades från föräldrar till barn var inom familjen Ädel. Anders Erik Ädels två söner Erik och Per bör ha introducerats i hantverket inom hemmet (Assis 2017) och de är bägge belagda som målare i skriftligt källmaterial. Sannolikt hade även äldste sonen Anders varit fadern behjälplig innan han skickades på lära till en spegelmakare i Söderhamn, där han dock omkom i en olycka. En av Ädels tre döttrar, Karin, kom i muntlig tradition att bli ihågkommen som en god konstväverska (LjM, Harald Grundells arkiv). Det förekommer även en obekräftad uppgift att Ädels hustru, Karin Ersdotter (1807-1858) ska ha varit Ädel behjälplig i måleriet (Assis 2017) och det bör inte uteslutas att fler kvinnor i familjen Ädel kan ha varit aktiva i målerihantverket, även om det inte kunnat beläggas.

Anders Erik Ädel (1809-1888) kom från enklare förhållanden. Fadern Anders Hurtig ${ }^{63}$ var indelt soldat, och föräldrarna flyttade från Söderhamn till Ljusdal, där hela familjen var bosatt från 1812. Flera hantverk utövades inom familjen. Hurtig var kunnig i hattmakeri och skrädderi och Ädels bror kom att syssla med skomakeri (KrA, Stamrullor Hälsinge reg). Någon koppling till målaryrket inom familjen är inte känd före 1830 då Ädel gifte sig med Karin Ersdotter, som var släkt med Hindriks-Olle. Några år senare målade Ädel tillsammans med Hindriks-Olle (Assis 2017). Mot slutet av 1830-talet arbetade Ädel på egen

61. Inredningen i Jon-Pers vilken bör ha tillkommit mellan 1830 och 1837 (Assis 2017). Pell-Pers i Noresbo finns illustrerad i Andersson 2000, fig. 119-120. Golvuret, daterat 1836, är målat av Ädel och förefaller vara en integrerad del i rummets helhet. Inredningen i övrigt har målats av Hindriks-Olle.

62. I såväl Utigården i Sunnanås (idag på Skansen) och i Ol-Mårs i Bäckebo, bägge tillkomna på 1830-talet (Sinha 2001; Assis 2016a; Andersson 2000), finns exempelvis taklister som bär ett annat manér än Hindriks-Olles.

63. Att Anders Hurtig (1789-1833) var Anders Erik Ädels biologiska far har inte tidigare kunnat beläggas, men detta är nu möjligt. År 1810 döms Ädels mor för lönskaläge (Söderhamn AI:16) och hon anger då förre hattmakarlärlingen Anders Nordlöf (senare Hurtig) som varandes fadern. Ett särskilt tack till Elvi Sandberg för denna uppgift. Ädels föräldrar gifte sig först 1812, efter moderns flytt till Ljusdal (Ljusdal EI:1). 
hand och kom att knyta egna kontakter med etablerade hantverkare. Han lärde bland annat känna Söderhamns stadsmålare Albert Blombergsson 1839 (Nyström \& Assis 2018). På 1850-talet hade han kontakt med spegelfabrikör Jon Rosenqvist (Söderhamn AI:18:240) genom att sonen Anders Ädel (1835-1852) kom dit som lärling. Vid denna tid var även en Lars Erik Hofrén ${ }^{64}$ från Arbrå lärling hos Rosenqvist, och Ädel bör då ha haft möjlighet att få kontakt med dennes släkting målaren Olof Hofrén i Arbrå.

Under lärotiden tog Anders Erik Ädel till sig Hindriks-Olles formspråk, vilket också syns i upplägg, motivval och detaljer i såväl inredningsmåleriet som möbelmåleriet. I början är influenserna tydliga, speciellt i enskilda detaljer, när Ädel målar kopior av Hindriks-Olles kokongblommor på ett golvursfodral från gården Pell-Pers i Noresbo daterat $1836 .{ }^{65}$ Även då Ädel börjat arbeta på egen hand, omkring 1837 , var han fortfarande beroende av sin lärares verk ikonografiskt. Tydliga exempel på det finns i tidiga inredningar. ${ }^{66}$ Under 1840 - och 1850 -talen utvecklade Ädel sitt hantverk och hans stil fick en mer självständig prägel genom att han tillförde egna element och detaljer. Han började använda flera moderna pigment och lade även till detaljer med oljeförgyllning i sitt måleri.

I flera av Ädels senare inredningar är det möjligt att ana spår av flera målares handlag, och det är sannolikt att dessa härrör från andra medlemmar ur familjen Ädel.

\section{Ljusdalsmålarnas motiv}

Motiven analyseras inte här för att peka på stilars spridning, utan för att visa hur likheter i motivval och utformningen av motiven kan synliggöra kopplingar människor emellan. När de olika motiven kopplas ihop med de namngivna målarna görs detta utifrån ett fåtal signerade verk, sådana med säkerställd proveniens och de genom konnässörskapsanalys attribuerade verken. Genom att studera några av de mer

64. Lars Erik Larsson Hofrén (f. 17/10 1833). Lärling och sedan gesäll hos fabrikör Rosenquist.

65. Golvur i privat ägo, målat för Per Persson (f. 1775) och Karin Persdotter (f. 1777). För illustration, se Andersson 2000.

66. En mycket stor del av Ädels detaljer i interiörerna från gårdarna Kvistens på Heden från 1839 och från Björs i Onsäng daterad 1844 går tillbaka på förlagor efter Hindriks-Olle. 
frekvent förekommande och för traditionen signifikativa motiven så är det möjligt att se hur de olika målarna tog över och förvaltade den föregående generationens upplägg och detaljer. Det ger en bild av hur målartraditionen utvecklades över tid, hur olika målare förhöll sig till och bidrog till traditionens utveckling, och kan styrka redan påvisade mästar-lärlingsförhållanden.

\section{Figur-och landskapsscener}

I flera av de verk som tillskrivits Arvid Andersson finns små scenerier innehållande landskap med små människofigurer - som delar av en större helhet. De förekommer såväl på möbler som i inredningar. I en del inredningar är scenerierna målade direkt på vägg men med inramningar som om de vore tavlor med ramar, ${ }^{67}$ en företeelse som var på modet omkring sekelskiftet 1800 . Scenerierna på de till Andersson attribuerade verken förefaller i allmänhet återge historiska eller påhittade händelser, och möjligen kan ett av dem tolkas som bibelhistorien om "Den förlorade sonen". Hindriks-Olle och Ädel förde denna tradition vidare, Hindriks-Olle genom ofta mer uttryckligt religiösa motiv, där ett troligen föreställer "Jona och valfisken" och ett annat någon form av brännoffer. ${ }^{68}$ Ädels motiv, såvitt det går att avgöra utifrån de attribuerade verken, kunde även de ha ett religiöst anslag (Andersson 2000, fig. 125 \& 127) men många av de bevarade scenerna är reducerade till enkla naturvyer utan uppenbar symbolisk betydelse. I herrstugan i Kristofers i Stene från 1854 lät han vyerna dominera över andra motiv. Då knöt han an till traditionen med "landskap mellan pelare", ett i södra Hälsingland förankrat motiv (Nylander 2003). Ädel kan ha inspirerats till detta genom inredningar han sett, men en direkt påverkan från andra aktiva målare kan heller inte uteslutas. Av Per Jonsson i Kolsvedja finns ett par möbler med små stadsmotiv som möjligen kan anknyta till traditionen med landskapsscenerier, men de har ingen som helst berättande karaktär utan påminner mer om de stiliserade stadsmotiv som dalmålarna så ofta använde.

67. Interiör från Per-Arvids i Sunnanås. Dokumenterad på foto och delvis bevarad som fragment i Ljusdalsbygdens museums samlingar. En oidentifierad målare har utfört liknande inredningar i Järvsö.

68. Interiörfragment med proveniens från gårdarna Simmes i Välje respektive Oppi-Berget i Bäckebo. Den tidigare med textbandet "Ära vare gud". 


\section{Rocailler}

I Arvid Anderssons inredning i Öje, rimligen utförd på 1790-talet, domineras ett väggfält av en stor blå rocaille. Flera liknande väggfält är kända från tiden ${ }^{69}$ och motivet bör ses som ett allmänt modeinslag. En av inredningarna kan troligen tillskrivas Jon Persson i Kolsvedja. Både Arve och de två målarna från Kolsvedja återkom till rocaillens former $\mathrm{i}$ flera andra målerier. Att döma av de till Arve attribuerade målningarna använde han dem på ett ganska fritt sätt, i såväl andra inredningar som på möbler, till exempel som inramningar till blomstermotiv. På detta vis förefaller även Per Jonsson och Jon Persson ha utnyttjat rocaillen och i deras möbelmåleri finns de i blå, gröna och röda färgställningar. Hindriks-Olle och Ädel förefaller enbart ha använt motivet i inredningsmåleriet. Hindriks-Olle använde rocaillen mindre fritt och utgick vad gäller såväl form som färg från en specifik förlaga på Ljusdals pre-

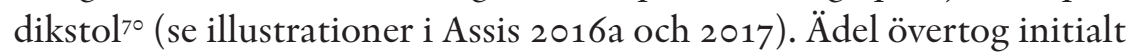
Hindriks-Olles sätt att använda motivet i inredningarna, vilket syns tydligt exempelvis i centralmotivet från Björs i Onsäng från 1844, men utan att vara bunden till förlagan. Efterhand blev Ädels användning av rocaillen friare och hans senare interiörer antyder att han snarare uppfattade den mer som en inramande och utfyllande mönsterform, än som ett enskilt motiv.

\section{Draperingar och girlanger}

I 1700-talets altaruppsatser i kyrkorna förekom ofta kolonner och målade draperingar. Samma element förekommer även flitigt i herrstugornas inredningar. Såväl Arvid Andersson och Hindriks-Olle som Ädel använde motivet. Hindriks-Olle målade i vissa fall draperierna virade runt kolonnerna, som i Anders-Jons i Stavsäter och i Anders-Pers i Nore, men ibland bara fritt hängande. ${ }^{71}$ Anders Erik Ädels beroende av Hindriks-Olle blir återigen tydligt genom detta exempel. Ädels två vanliga sätt att lägga upp samma motiv är båda varianter av förebilder från Hindriks-Olle. Det kan till exempel ses i en inredning från Björs i Onsäng målad 1844. Där efterbildade Ädel de draperier som Hindriks-Olle

69. Kammarinteriör i Hans-Ers i Ångsäter, samt fragment från Höga. LjM, bildarkiv.

70. Den idag förgyllda förlagan, under predikstolskorgen i Ljusdals kyrka, var ursprungligen färgsatt i gulorange och ljust rött.

71. I exempelvis gårdarna Pell-Pers i Noresbo, Simmes i Välje och Oppi-Berget i Bäckebo. 
omkring 1836 hade målat i Pell-Pers i Noresbo. Inredningsarbetet i PellPers var troligen ett av de tillfällen där Ädel också medverkade under ledning av Hindriks-Olle. I Kristofers i Stene kopierade Ädel en annan av Hindriks-Olles varianter på motivets upplägg, vilket finns bevarat från den idag rivna gården Anders-Pers i Nore, idag i Ljusdalsbygdens museums samlingar. Alla tre målarna, Arve, Hindriks-Olle och Ädel använde även draperier för att dekorera möbler, exempelvis mössbord och insidan av locken på skrin och kistor. I Kolsvedja-målarnas kända verk är målade draperingar i princip obefintliga, så när som på i ett fall, Per Jonssons kista från 1793 där motivet förekommer på kistans front.

\section{Korset med kransen}

Korset med kransen har tidigare uppmärksammats i Anders Erik Ädels måleri, och förlagan har föreslagits vara en altarprydnad från Järvsö kyrka (Andersson 2000:134f). Motivet var samtidens vanligaste typ av altarprydnad, enligt Hedvig Brander Jonssons avhandling (Brander Jonsson 1994:63) varför inspiration från annat håll inte kan uteslutas. Bevarade exempel finns i Segersta, Arbrå och på ljudtaket till Färila predikstol. Fler har funnits men de har ersatts av andra altarprydnader vid renoveringar (t.ex. Söderala och Mo). Motivet går betydligt längre tillbaka och Arvid Anderssons användning av det på 1790-talet går tillbaka på äldre förebilder, som till exempel motiven på Granlunds predikstolar i Ljusdal respektive Järvsö från tidigt 1770-tal. ${ }^{72}$ I Ädels tidigaste kända inredning med motivet, från 1844, saknar korset krans men därefter tycks han konsekvent ha avbildat korset med kransen. Utöver dessa två målare har motivet även använts av minst tre andra, oidentifierade målare, verksamma inom samma tradition. ${ }^{73}$

\section{Hängande bok}

Motivet med den uppslagna boken hängande i en girlang användes av Arve, Hindriks-Olle, Ädel samt av en okänd målare och alla nyttjade de motivet på likartat vis. ${ }^{74}$ Motivet förekom redan 1807 i den till Arve attribuerade inredningen från Östigården i Ed, Färila, idag på Färila

72. Motivet föreslogs som altaruppsats i Arbrå redan på 1790-talet, se Nodermann 2005:59.

73. Deras användning, i två olika gårdar i Delsbo, kan sägas vara kopior av Ädels upplägg av motivet.

74. Fragment av riven inredning av oidentifierad målare, från Ol-Mårs i Bäckebo, Ljusdal, daterad 1828. 
hembygdsgård. Hindriks-Olle gjorde 1830 i Simmes, Välje även en variant på motivet, där han ersatte boken med ett pappersark, ett utförande som Ädel uppenbarligen tog efter i en inredning från Ol-Görs i Våga, Järvsö, från 1854. Motivet är inte känt i verk attribuerade till målarna från Kolsvedja. Motivet förekommer även skuret i trä i Ljusdals kyrka på läktaren ovanför mittgången samt på nummertavlorna. Läktaren i sin nuvarande form är dock tillkommen senare än 1807 då Arve bevisligen använde motivet i Färila. Det är oklart om läktardekorationen är samtida med läktaren, eller möjligen en återanvänd del från den äldre läktare som fanns innan. Inte heller nummertavlornas tillkomstår är känt, och även de kan möjligen ha varit inspirationskälla för de lokala målarnas användning av motivet.

\section{Girlanger}

De tidiga målarna, Jonsson och Andersson, använde vertikalt hängande girlanger som motiv ytterst sparsamt. De var i det tidiga skedet främst vanliga i snickeriet, för att senare även bli vanliga i måleriet. Arvid Andersson, som också var snickare, skar dem i trä på ett numera försvunnet dörröverstycke (NM 172.K.z), och möjligen var han en av dem som bidrog till att motivet tidigt överfördes till måleriet. På 1830-talet brukades motivet ofta av såväl Hindriks-Olle som Ädel. ${ }^{75}$ En liknande utveckling ses i användningen av de horisontellt upphängda girlangerna. De förekommer sparsamt hos de tidiga målarna, som på ett klockfodral från $1806^{76}$ attribuerat till Arve för att senare användas alltmer frekvent av Hindriks-Olle, Jon Persson och Anders Erik Ädel.

\section{Blomstermotiv}

Blomstermotiv i form av så kallade ädelblommor, är det mest kännetecknande för måleriet i området. I dagsläget är Arvid Andersson den äldste identifierade lokale målare som införde blomstermotiv av denna typ i sitt måleri, bland annat i en till honom attribuerad 1700-talsinredning från byn Lock i Ljusdal, som idag är riven. Under tidigt 1800-tal blir blomuppsättningar en allt viktigare del i inredningarna, för att i vissa fall dominera totalt såsom i den till honom attribuerade

75. Klockrankor av Hindriks-Olle: Ol-Ors i Stavsäter och Ol-Mårs i Bäckebo. Av Ädel: Kvistens på Heden och Fiens i Sörkämsta. Samtliga i Ljusdal.

76. Klocka från Baggbo, Ljusdal, målad för Lars Johansson och Gölin Andersdotter. I Hälsinglands museums samlingar. 
inredningen i Utigården i Sjövästa från 1807. Ofta är hans blommor i bukett, men de förekommer även placerade i urnor. Samtliga beskrivna målare använde motivet frekvent, i likhet med flera andra samtida lokala målare, identifierade och okända. Motiven utfördes ofta på mycket likartade sätt och många möbler har en målad dekor som enbart består av blomstermålerier i kombination med ägarnamn och årtal. Handlaget i detaljernas utförande blir då helt avgörande för attribueringar till respektive målare.

\section{"Kokonger" och "snirkliga strån"}

Över tid tillkom enskilda detaljer i blomstermåleriet. De kan beskrivas som "snirkliga strån" och "kokonger". Främst är de kända hos Hindriks-Olle och Anders Erik Ädel under 1830-talet, men de förekommer även tidigare, bland annat i Per Jonssons möbelmåleri från sekelskiftet 1800. Detaljerna tycks som ovan nämnts vara inspirerade från någon samtida förlaga, såsom den tryckta tapet som illustreras i figur 5 a. Hos Hindriks-Olle förekommer kokongerna dels som vita "getingbon"; i till exempel interiörer från Höga, Ol-Mårs och Hindriks, ${ }^{77}$ dels sammanväxta med en blomma, ofta målad i rött. ${ }^{78}$ En variant av kokongen som del av en blomma förekommer i några verk tillskrivna Ädel och de har dateringar från tiden då denne står under Hindriks-Olles inflytande..$^{79}$ De snirkliga stråna tar Ädel också till sig, men han låter dem ta mera plats och gör dem i ett mer flyhänt manér än Hindriks-Olle.

\section{Schabloner}

Schabloner är ovanliga i det tidiga Ljusdalsmåleriet, men de förekom sparsamt hos Hindriks-Olle och de blev ett tidvis betydande inslag i Ädels måleri. Båda två integrerade dem i sitt frihandsmåleri, men Hindriks-Olle på ett mer fantasifullt och finurligt sätt än Anders Erik Ädel.

77.Höga, ensamgård nära Ljusdals kyrka, Ol-Mårs i Bäckebo och Hindriks i Kallmyr.

78. I till exempel Lasses i Edänge, Ol-Ors i Stavsäter och Per-Ers i Hamre.

79. Förekommer i ett par möbelmålerier från 1836, som exempelvis på klockan från gården Pell-Pers i Noresbo, Ljusdal. Klockan med kokongblommorna kan tillskrivas Ädel, medan interiören i övrigt är utförd av Hindriks-Olle. 


\section{Folklig konst - kollektiva formspråk förvaltade av individer}

Ljusdalsmåleriet, såsom det är känt vid 1800-talets mitt, utvecklades lokalt från de sista decennierna på 1700-talet, då det ersatte ett äldre inredningsideal. Avgörande faktorer som bidrog till denna utveckling var troligen de personliga kontakter som lokala målare och snickare vid denna tid fick med de två skråutbildade hantverkarna Magnus Granlund och Paul Hallberg, samt de arbeten som utfördes i socknens kyrka under 1770-talet. Granlund och Hallberg introducerade nya formspråk och motiv som kom att ligga till grund för den lokala stilutvecklingen långt in på 1800-talet. Flera olika målare förvaltade denna lokala måleritradition och traderade dess motiv och estetik från generation till generation.

Målarna Arve i Stavsäter och Per Jonsson var två tidiga företrädare för denna tradition och de fick flera efterföljare. Per Jonssons son, Jon Persson, förvaltade faderns bildspråk och utvecklade det under 1800-talet. Från Arvid Andersson fördes traditionen vidare genom hans lärling Hindriks-Olle och vidare till Anders Erik Ädel. Både Hindriks-Olle och Ädel utvecklade med tiden delvis egna detaljer och formspråk. De kom att göra avtryck i den lokala traditionen, men de båda bör ses i ljuset av sina sammanhang.

Samtliga av de målare som här presenterats verkade inom samma tradition och i samma sociala kontext. Utöver dem fanns ytterligare målare och de förvaltade alla en mängd olika motiv och detaljer som tillsammans bildade det formspråk som blev så typiskt för måleriet i socknarna i övre Ljusnandalen. Traditionen förändrades över tid. Vissa motiv föll ifrån och andra tillkom. Men många av dem var i bruk under flera generationer. I möbelmåleriets olika komponenter går det att jämföra alla de presenterade målarna. I kedjan från Arve till Ädel är det också möjligt att följa utvecklingen av inredningsmåleriets olika delar. Alla målarna hade möjligheter att studera kyrkoinredningar och mycket inspiration är uppenbarligen hämtad därifrån, men andra tänkbara inspirationskällor skall inte glömmas. Ännu vet vi inget om var de äldre målarna hade lärt sig hantverket, och vad de kan ha fått med sig från ungdomsåren i form av utbildning och kontakter. Arve i Stavsäter och Hindriks-Olle hade också av allt att döma tillgång till bildförlagor, och kanske har även de andra målarna haft tillgång till sådana källor.

Försök till attribueringar kompliceras av att målarna på landsbygden 
sällan strävade efter att vara unika vad gäller formspråk och uttryck, utan snarare höll sig inom den rådande konventionen. Många samtida målares motiv kan därför vara så lika att det endast blir handlag, individuella materialval och personligt utformade detaljer som kan särskilja den ene hantverkarens alster från den andres.

Som helhet visar Ljusdalsmåleriets bevarade interiörer, möbler och andra föremål från 1800-talets första hälft, och kunskaperna om detta, på betydelsen av nätverk och personliga band för utvecklingen av det varierande formspråk inom ett gemensamt ramverk som är så typiskt för i stort sett all folklig konst. Varje enskild individ kunde påverka och utveckla men var primärt en del av en sammanhållande tradition som förvaltades från generation till generation.

\section{"Ädelmåleriet" som begrepp}

I dagsläget finns cirka 30 stycken till namnen kända lokala målare i Ljusdal och Färila socknar, som alla bör ha varit aktiva inom hantverket vid olika tidpunkter under perioden 1750-1870. Flera av dessa har kategoriserats som utövare av den ovan skrivna traditionen, som i folkmun och i forskningen har kallats "ädelmåleri".

Även om Jon Persson i Kolsvedja i sina målerier motivmässigt utgick från faderns måleri så kan hans verk, till skillnad från faderns, i många avseenden räknas in i denna lokala tradition. Detta är ett av de exempel som visar det problematiska i benämningen "ädelmåleri". Persson såväl som Arve i Stavsäter bör räknas till dem som var med under utvecklingen av den lokala stilen, som växte fram ur rokokon och under påverkan av den gustavianska stilen. Dessa bägge målare var aktiva långt innan Anders Erik Ädel ens var född. En annan av Ädels föregångare som var med och stakade ut vägen var Hindriks-Olle. Ädel har tidigare lyfts fram som den främste inom traditionen, men materialet visar att han i början av sin bana var mycket beroende av Hindriks-Olle och kopierade dennes repertoar. Tekniskt sett blev han heller aldrig lika skicklig som sina föregångare. Termen ädelmåleri som benämning på den lokala måleritraditionen i Ljusdals socken blir då snarast en belastning då den tenderar att cementera en alltför onyanserad bild av förhållandena. 


\section{Referenser}

\section{Otryckta källor}

Harald Grundells arkiv, Ljusdalsbygdens museum.

Krigsarkivet (KrA) 1815, Stamrullor Hälsinge regemente 1815.

Ljusdals kyrkoarkiv, Ljusdal EI:1.

Ljusdals kyrkoarkiv. LIb:4, Kyrkoräkenskaper 1766-1801; EI:1, Lysnings och vigselbok 1732-1830; LI:12, Kyrkoräkenskaper 1801-1835; KI:2, Sockenstämmoprotokoll 1755-1793 (s. 8: 1777 och 1778); KI:3, Sockenstämmoprotokoll m.m. $1795^{-1816 .}$

Ljusdals tingslags häradsrätt FII:6, Bouppteckningar, (nr 130 Johan Persson 17461817).

Ljusdalsbygdens museums arkiv (LjM OPR). Opublicerade rapporter, utredningar och dokumentationer; Assis: Inredningsmålerier i Ljusdal omkring 1750-talet. Liten bildsamling; Assis: Några hantverkare belagda i Ljusdals kyrkoräkenskaper i samband med Paul Hallberg; Assis: En inredning på puts i Hans-Ers i Ångsäter, dokumenterad 2011.

Nordiska museets arkiv (NM). Nordiska museets fotografier: foto 172.K.z.

Söderhamn Husförhörslängder AI:18:240.

Söderhamns stad Rådhusrätt och magistrat (X) AI:16 (1810-1813).

\section{Tryckta källor}

Andersson, Maj-Britt (2000). Allmogemålaren Anders Ädel. Stockholm: Prisma.

Assis, Anders (2013). Tre brudhimlar och ett ovädersmoln. Hälsingerunor 2013.

Assis, Anders (2016a). Att spåra en okänd målare. Museivännen 2016:1. Ljusdal: Ljusdalsbygdens museum.

Assis, Anders (2016b). Ljusdals många allmogemålare och bygdeforskaren Carl Perssons källvärde. Hälsingerunor 2016.

Assis, Anders (2017). Jon-Pers i Nore, nytt ljus över Ädelmåleriet. Museivännen 2017:2. Ljusdal: Ljusdalsbygdens museum.

Assis, Anders (2018). Snickaren Johan Persson skar girlander på brudstolar och klockfodral. Hälsingerunor 2018.

Brander Jonsson, Hedvig (1994). Bild och fromhetsliv i 1800-talets Sverige. Diss. Uppsala: Uppsala universitet.

Brännberg, Gudrun (2007). Målare i Medelpad 1700-1890. Mjölby: Atremi.

Cavallin, Isabell (2010). När väggarna talar: en gårds historia i relation till dess interiör. Kandidatuppsats i kulturstudier. Högskolan på Gotland, Institutionen för kultur, energi och miljö.

Kämsby, Eva (1999). Ett Ljusdalsskåp. Medlemsblad för Ljusdalsbygdens museums vänner. Ljusdal: Ljusdalsbygdens museum.

Nodermann, Maj (2005). Mästare och möbler: jämtländska målare, bildhuggare, hantverkare och deras produkter. Östersund: Jamtli förlag.

Norrman, R. (red.) (2001). Uppsala stifts herdaminne II:16. Uppsala.

Nylander, Lars (2003). Allmogemålaren Eric Ericsson och inredningsmåleriet i södra Hälsingland vid 1800-talets mitt. Hälsingerunor 2003. 
Nylander, Lars (2008). Albert Blombertsson: liv och konst. Helsingiana. Hudiksvall: Hälsinglands museum.

Nylander, Lars, Daniel Olsson \& Bo Ulfhielm (2016). Fiskarkapell $i$ Gästrikland och Hälsingland. Gävle och Hudiksvall: Hälsinglands museum \& Länsmuseet Gävleborg.

Nyström, Ingalill \& Anders Assis (2018). Handeln med färger i Hälsingland under 1700- och 1800-talen. Rig: kulturhistorisk tidskrift 2018:2-3.

Rapp, Bengt (1968). Målaren Paul Hallberg $i$ Hudiksvall och hans nürnbergska kopparstycken: bidrag till det svenska sjuttonhundratalets ikonografi. Antikvariskt arkiv 34. Stockholm: Almqvist \& Wiksell.

Sinha, Kerstin \& Gärd Folkesdotter (2002). Bild på bondevägg: hälsingegårdarnas måleri. Hudiksvall: Hälsinglands museum.

Telhammer, Ingrid (1978). Predikstolsmakare och predikstolskonst före 1777 i norra Hälsingland, Medelpad och Angermanland. Umeå: Kungl. Skytteanska samfundets handlingar $\mathrm{nr} 20$.

Telhammer, Ingrid (1980). Ljusdals kyrka. Serie: Hälsinglands kyrkor 35, Uppsala: Ärkestiftets stiftsråd.

Telhammer, Ingrid (1995). Måns Granlund: en svensk bildhuggare på 1700-talet. Stockholm: Kungl. Vitterhets-, Historie- och Antikvitetsakademien.

Tunander, Pontus \& Lena Nessle (1995). Skönt målat: dekorationsmåleriet genom tiderna. Västerås: Ica. 